https://nv.nltu.edu.ua

https://doi.org/10.36930/40310116

$@ \bowtie$ Correspondence author

Article received 22.01.2021 p.

Article accepted 04.02.2021 p.

O. M. Fedoryshyn

UDC 615.014.2:582.99

О. М. Федоришин, Д. С. Загородня, А. С. Крвавич, А. О. Милянич, Р. О. Петріна

Національний університет "Львівська політехніка", м. Львів, Україна

\title{
РОЗРОБЛЕННЯ ТЕХНОЛОГІЧНОЇ СХЕМИ ЕКСТРАКЦІЇ КОРЕНІВ CARLINA ACAULIS
}

Розроблено технологічні схеми одержання екстрактів коренів Carlina acaulis, які дали змогу отримувати вторинні метаболіти лікарських рослин для виробництва фармацевтичних препаратів. Carlina acaulis $\epsilon$ лікарською рослиною, яка нині $\epsilon$ недостатньо вивченою. Відомо, що корені містять дубильні та смолисті речовини, інулін (12-18 \%), барвники, ефірну олію (1-2 \%) та цукор. Встановлено, що для максимального вилучення фенольних сполук і флавоноїдів потрібно правильно підібрати ефективну технологію екстрагування. Розроблено на підставі кінетичних закономірностей екстрагування технологічні схеми двома способами - настоюванням та настоюванням 3 перемішуванням в апараті з мішалкою. Запропоновано як екстрагент використати 70 \% водно-етанольну суміш, співвідношення сировина: екстрагент - 1:10, розмір частинок 2 мм. Встановлено, що час екстрагування методом настоювання становить 48 год, методом настоювання 3 перемішуванням - 3 години. Отримано настоянку в'язкої консистенції, світло-коричневого кольору із вмістом етанолу не більше $15 \%$, сухим залишком не менше 70 \% і також перевірено на мікробіологічну чистоту. Технологічна схема виробництва містить підготовку рослинної сировини (подрібнення, просіювання, зважування), отримання первинної витяжки (мацерація) та фільтрування й освітлення настоянки (очищення від баластних речовин способом охолодження, відстоювання, фільтрування та ін.). Зроблено висновок, що на підставі розроблених технологічних схем можна отримувати екстракти C. acaulis з максимальним виходом фенольних сполук та флавоноїдів. Одержані настоянки мають високі органолептичні та фізико-хімічні показники та можуть застосовуватись як лікарський засіб.

Ключові слова: екстракт; настоювання; фенольні сполуки; флавоноїди; вторинні метаболіти; технологічна схема.

\section{Вступ}

Лікарські рослини містять у своєму складі багато вторинних метаболітів, які мають певні фізіологічні дії на організм людини та $€$ важливим джерелом для сучасних фармацевтичних препаратів $[1,8]$. На сьогодні у косметичних, фармацевтичних та гігієнічних засобах використовують екстракти близько 70 тис. видів рослин, 15 тис. $з$ яких є рідкісними за даними Міжнародного союзу охорони природи [7].

Carlina acaulis є лікарською рослиною, яка згідно 3 даними Червоної Книги України має вразливий природоохоронний статус [4]. Це багаторічна трав'яна рослина, яка належить до класу дводольних (Magnoliopsida), сімейство Asteraceae (Compositae) [3]. Найпоширеніше місцезнаходження є територія Західної України, а саме українські Карпати з унікальними кліматичними умовами існування [5].
На ефективність вилучення вторинних метаболітів 3 лікарської рослинної сировини впливає багато чинників, а саме природа та розмір сировини, розчинник, який використовують для екстракції, технологічний процес виробництва (технологія екстракції), обраний тип обладнання, співвідношення сировина: екстрагент та природа речовин, які треба вилучити із сировини. Використання відповідної технології екстракції, рослинного матеріалу, виробничого обладнання, способу екстракції та розчинника, а також дотримання належних виробничих практик, допомагають отримати високоякісний екстракт.

Об'єкт дослідження - процес екстрагування фенольних сполук і флавоноїдів методом настоювання та за допомогою перемішування в апараті з мішалкою.

Предмет дослідження - екстракти коренів C. асаиlis, отримані методом настоювання та методом настоювання в апараті з мішалкою.

\section{Інформація про авторів:}

Федоришин Ольга Миколаївна, асистент, кафедра технології біологічно активних сполук, фармації та біотехнології. Email: oljalvivua@gmail.com; https://orsid.org/0000-0002-3113-8243

Загородня Діана Сергіївна, студент, кафедра технології біологічно активних сполук, фармації та біотехнології. Email: diana.s.zahorodnia@lpnu.ua; https://orsid.org/0000-0002-3311-5213

Крвавич Анна Сергіївна, ст. викладач, кафедра технології біологічно активних сполук, фармації та біотехнології. Email: annaKrv85@gmail.com; https://orsid.org/0000-0002-7402-2689

Милянич Андрій Остапович, канд. хім. наук, доцент, кафедра технології біологічно активних сполук, фармації та біотехнології. Email: andrii.o.mylianych@lpnu.ua; https://orsid.org/0000-0002-6180-9925

Петріна Романа Омелянівна, канд. техн. наук, доцент, кафедра технології біологічно активних сполук, фармації та біотехнології. Email: romanna.o.petrina@Ipnu.ua; https://orsid.org/0000-0002-5416-1999

Цитування за ДСтУ: Федоришин О. М., Загородня Д. С., Крвавич А. С., Милянич А. О., Петріна Р. О. Розроблення технологічної схеми екстракції коренів Carlina acaulis. Науковий вісник НЛтУ України. 2021, т. 31, № 1. С. 93-98.

Citation APA: Fedoryshyn, O. M., Zahorodnia, D. S., Krvavych, A. S., Mylyanych, A. O., \& Petrina, R. O. (2021). Development of technological scheme of Carlina acaulis root's extraction. Scientific Bulletin of UNFU, 31(1), 93-98. https://doi.org/10.36930/40310116 
Мета роботи - розробити технологічну схему екстракції коренів Carlina acaulis, яка буде враховувати виходи фенольних сполук і флавоноїдів, тривалість екстракції та подрібнення сировини.

Для досягнення мети визначено такі основні завдання дослідження:

- оцінити стан досліджень $C$. acaulis у вітчизняній та закордонній літературі;

- проаналізувати наявні технології та визначити напрямки удосконалення технологічної схеми для максимального вилучення цільових компонентів 3 коренів $C$. acaulis.

Наукова новизна отриманих результатів дослідження - вперше розроблено технологічну схему одержання настоянки коренів C. acaulis методом настоювання та в апараті з мішалкою для вилучення фенольних сполук і флавоноїдів.

Практична значущість отриманих результатів дослідження - запропоновані технологічні схеми екстрагування можуть бути впроваджені у виробництво для виготовлення настоянок коренів C. acaulis або як компоненти для виготовлення комбінованого засобу.

Аналіз останніх досліджень та публікацій. Опрацювання й аналіз сучасних джерел інформації, наукової літератури та перегляд колекційних фондів нашої держави вказує на поширення і стан популяції цього виду. Розповсюдження європейського субальпійського виду C. acaulis захоплює гори Південної і Середньої Свропи (Піренеї, Альпи, Аппеніни, Юра, Балкани і Карпати). Також поширений в Румунії на масиві Жілеу (Бігарські гори), Латвії і Литві, трапляється в Білорусі. Популяції $C$. acaulis переважно ростуть на кам'янистих розсипах, скелях, щебенистих, дренажних грунтах, свіжих задернованих ділянках у межах висот 1500-2000 м н.р.м. [4]. В українських Карпатах C. acaulis зростає на висоті від 900 до 1920 м н.р.м., а у Східних Горганах на околицях сіл Ямна та Яблуниця, також на лісових галявинах смт Ворохта і с. Зелена Надвірнянського р-ну ІваноФранківської обл. цей вид росте на висоті 760-800 м н.р.м. Виявлені також на території Сколівських Безкидів у Сколівському р-ні с. Глинкувате (полонина Чорна Ріпа) $[3,5]$.

Відносно фітохімії та фармакологічної активності рослини, то інформація є обмежена. Є деякі дані, що корінь $C$. acaulis містить дубильні й смолисті речовини, інулін (12-18\%), барвники, ефірну олію (1-2\%) та цукор $[3,14]$. Досліджено також оксид карліну, який має дезінфікувальну дію, дубильну кислоту, камедь і низку елементів, таких як калій, кальцій і магній. Бензил-2фурацителен - "карліна оксид" є головною складовою частиною ефірної олії із коріння C. acaulis [10].

Використання в медицині залишається недостатньо вивченим, оскільки результати дослідження in vitro на коренях є дуже обмеженими. Рослину широко застосовують у народній медицині завдяки комплексу речовин, що містяться в ній, стимулюють різні системи організму, позитивно впливають на їх недостатню функцію (ефірна олія діє бактерицидно, а настій порошку кореня на вині виганяє гельмінтів). Рекомендують міцним відваром обмивати рани, які погано загоюються, лікувати інші захворювання шкіри. Не виявлено важливих протипоказів щодо застосування рослини, окрім побічних ефектів у вигляді нудоти і блювоти в разі передозування та дитячий вік. Застосовують також у тваринництві [15]. У традиційній медицині препарати C. acaulis зас- тосовують у разі загальної загальмованості кори головного мозку, дисфункції вищої нервової діяльності через вагітність. Лікарська рослинна сировина входить до складу відомих зборів: "Еліксир здоров'я", який виготовляє українська фармацевтична компанія "Здоров'я", "Шведська гіркота Доктора Тайса (виробник "Dr. TheissNaturwaren GmbH", Німеччина). Про результати позитивної дії шведських трав свідчить безліч відгуків [9].

Багаторічний досвід лікування рослинами вимагає наукового аналізу та дослідження за допомогою сучасних фітохімічних методів дослідження. Особливу увагу на сьогодні приділяють дослідженням біологічної активності $C$. acaulis, що застосовують у фармацевтичній та медичній галузях [2, 6, 11, 12, 13].

Завдяки наявності в рослині біологічно активних речовин із різноманітною фармакологічною дією $\epsilon$ можливість застосовувати іiі для лікування багатьох захворювань. Важливим залишається дослідження вітчизняної сировини. Завдання дослідження проаналізувати наявні технології та визначити напрямки удосконалення технологічної схеми для максимального вилучення цільових компонентів 3 коренів C. acaulis.

Настоянки, як рідкі лікарські форми, зазвичай отримують $з$ лікарської рослинної сировини екстракцією біологічно активних речовин водно-етанольним розчином без нагрівання та видалення екстрагента; при цьому співвідношення рослинна сировина: екстрагент, зазвичай, дорівнює 1:5 або 1:10. Концентрацію екстрагенту підбирають експериментально за принципом максимального екстрагування діючих речовин в найкоротші терміни за мінімального вилучення супутніх речовин. У фармацевтичному виробництві при цьому найчастіше застосовують такі методи одержання, як протитечійна екстракція, мацерацій (часто 3 циркуляцією екстрагента або механічним перемішуванням) чи циркуляційне екстрагування (з використанням легколетких екстрагентів).

Екстракційні процеси часто називають дифузійними, тому що рушійною силою перенесення цільових компонентів з вихідної суміші в екстрагент $є$ різниця концентрацій. Механізм екстрагування залежить від стану частинок твердої фази, а також від температури, концентрації, часу і від природи розчинника (екстрагента). Механізм вилучення цільових компонентів із твердих матеріалів визначається такими стадіями:

1) рух розчинника (екстрагента) до цільового компонента, що перебуває у твердому матеріалі;

2) взаємодія розчинника з компонентом, що вилучається;

3) перенесення маси вилученого компонента до границі розділу рідкої і твердої фази;

4) перенесення маси вилученого компонента через пограничний шар;

5) перенесення маси цільового компонента від пограничного шару в шар потоку розчинника.

При виборі способу екстракції важливим показником є досягнення рівноважної концентрації компонента, що вилучається, в розчині і концентрації насичення. Під час екстракції без перемішування, за відсутності конвекції, коефіцієнт конвективної дифузії дорівнює нулю, а товщина дифузійного шару стає рівною товщині усього шару екстрагента. Отже, коефіцієнт масопередачі визначається тільки внутрішньою дифузією в сировині і вільною молекулярною дифузією в нерухомій рідині. 
При екстракції хоча б з незначною швидкістю, зменшується шар нерухомої рідини, з'являються конвекційні потоки, які сприяють перенесенню речовини. Такий режим екстрагування характерний для мацерації з перемішуванням, перколяції, швидкоплинній реперколяції, безперервній протитечійній екстракції та ін.

Фенольні сполуки та флавоноїди, які містяться у коренях $C$. acaulis, мають високу біологічну дію і їх максимальне вилучення залежить від ефективної технології отримання екстрактів, а саме від способу екстракції.

\section{Результати дослідження та їх обговорення}

Попередніми дослідженнями оптимізовано умови проведення екстракції коренів $C$. acaulis для максимального вилучення фенольних сполук та флавоноїдів. Це насамперед пов'язано 3 використанням густих екстрактів у якості лікарських засобів. Використання рослинної сировини дає змогу отримати препарати 3 м'якою терапевтичною дією, відсутністю побічних ефектів, гіпоалергенні. Актуальним є розроблення технології одержання настоянки, враховуючи умови екстракції. Оптимальними умовами екстракції $є$ : використання як екстрагента $70 \%$-го етанолу, коренів $C$. acaulis діаметром частинок 2 мм, співвідношення сировина: екстрагент - 1:10, кратність екстрагування - 4 . Використовуючи ці дані, було розроблено технологічні схеми отримання екстракту з коренів C. acaulis.

Унаслідок вивчення кінетичних закономірностей екстрагування фенольних сполук і флавоноїдів 3 коренів C. acaulis для отримання первинної витяжки пропо- нуємо до використання два способи екстракції: настоювання і настоювання з перемішуванням.

Технологічна схема процесу одержання настоянок 3 коренів Carlina acaulis методом настоювання. Технологічний процес починається 3 підготовки рослинної сировини. Корені заготовлюють в короткий період восени, тому роблять запас 3 урахуванням річної потреби, їх миють, подрібнюють та висушують. У сухому стані сировина може зберігатись на підприємстві до нового врожаю весь рік. Висушену сировину подрібнюють до 1-2 мм, просіюють через сито та зважують.

Далі відбувається екстрагування, отримання первинної витяжки (мацерація) та фільтрування. Для максимального вилучення фенольних сполук та флавоноїдів доцільно проводити 4-кратне екстрагування методом настоювання, що є найбільш економічно вигідним.

Далі проводять освітлення настоянки (очищення від баластних речовин способом охолодження, відстоювання, фільтрування та ін.), стандартизацію (аналіз, доведення до стандарту) та фасування, упаковування.

Проведені експериментальні дослідження з вивчення кінетики екстрагування флавоноїдів та фенольних сполук з коренів Carlina acaulis методом настоювання показали, що в ролі екстрагенту оптимально використовувати $70 \%$ водно-етанольну суміш, а час досягнення рівноваги дорівнює 48 год.

Технологічну схему екстрагування коренів $C$. acaulis подано на рис. 1. Попередньо підготовлену очищену і висушену рослинну сировину коренів Carlina acaulis iз бункера Б-1 подають у коренерізку із гільйотинними ножами К-1, в якій іï подрібнюють.

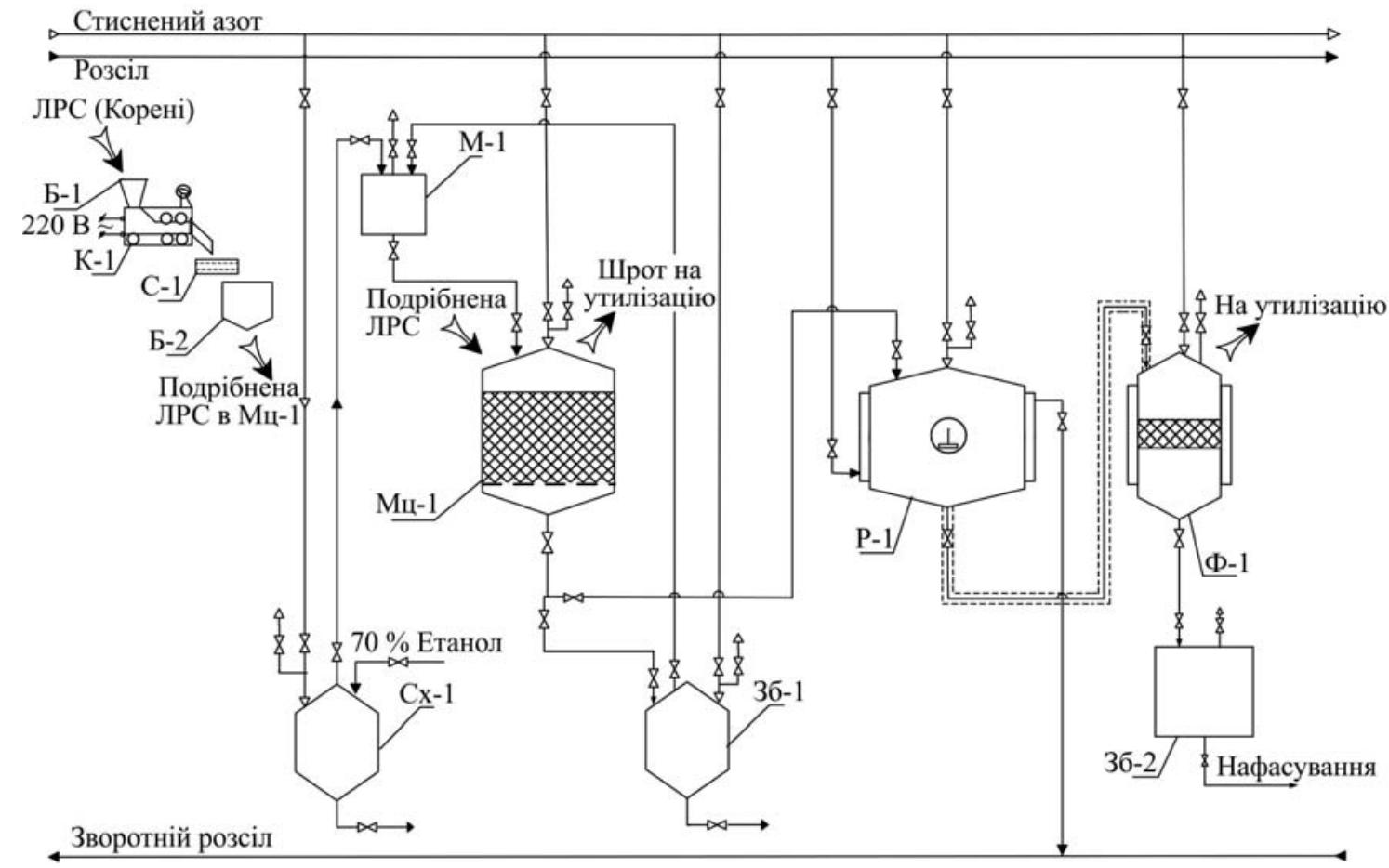

Рис. 1. Технологічна схема процесу одержання настоянок з коренів Carlina acaulis методом настоювання: Б-1, Б-2 - бункери; Сх-1 сховище; М-1 - мірник; К-1 - коренерізка; С-1 - сито; Мц-1 - мацератор; Р-1 - реактор; Ф-1 - друк-фільтр; 3б-1, Зб-2 - збірники

Оскільки куски подрібненого матеріалу завжди неоднакові за своїм розміром, тому здійснюють просіювання для відокремлювання крупніших та пилуватих частинок від основної маси на ситах С-1. Проведені дослідження показали, що для екстракції найефективнішим буде відсів 3 розміром частинок 2 мм, який збирають в бункер Б-2 та подають на стадію екстрагування.
Далі використовують найпростіший і найдревніший спосіб екстрагування рослинної сировини - метод настоювання (мацерація). Для отримання настоянок з коренів Carlina acaulis цим методом, з бункера Б-2, відбирають і відважують необхідну кількість подрібненої сировини та завантажують у мацератор Мц-1, на перфорованому фальшдні якого попередньо розміщено фільтру- 
вальний матеріал (фільтрувальний папір або бязь). Зі сховища CX-1 через мірник М-1 в мацератор подається водно-етанольна суміш. Екстрагент заповнює внутрішній об'єм апарату до утворення над рослинною сировиною дзеркала рідини. Далі проводять процес настоювання, який триває 48 годин. Після чого отриману витяжку перетискають стиснутим інертним газом (азотом), крізь фільтрувальний матеріал, що розташований на решітці в нижній частині мацератора, в реактор Р-1.

Після настоювання і фільтрування, виснажену сировину додатково промивають невеликою кількістю екстрагенту. При цьому отриману витяжку з малим вмістом екстрагованих речовин збирають у збірнику 3б-1.

Далі відпрацьовану рослинну сировину вивантажують 3 мацератора, замінюють фільтрувальний матеріал, а тоді завантажують нову порцію подрібнених коренів. Після цього із збірника 3б-1 через мірник М-1 в мацератор подають за допомогою стисненого інертного газу збіднену витяжку для змочування фітосировини., а тоді iз сховища $\mathrm{Cx}-1$ додають необхідну кількість чистого екстрагенту. Знову проводять процес настоювання, як описано вище.

Освітлення настоянки проводять в реакторі P-1, який обладнаний оболонкою та лопатевою мішалкою. У реакторі Р-1 суміш відстоюється та освітлюється під час охолодження. Охолоджують суміш до температури $+4-+8{ }^{\circ} \mathrm{C}$ пуском розсолу в оболонку реактора. Для інтенсифікації теплообміну в апараті суміш спочатку повільно перемішується до досягнення необхідної температури в усьому об'ємі екстракту, а далі відстоюється без перемішування впродовж 0,5-1 доби. Після відстоювання, настоянку холодною фільтрують від частинок, що випали в осад.

Фільтрацію одержаного екстракту проводять на друк-фільтрі Ф-1, що працює під тиском. Очищений від

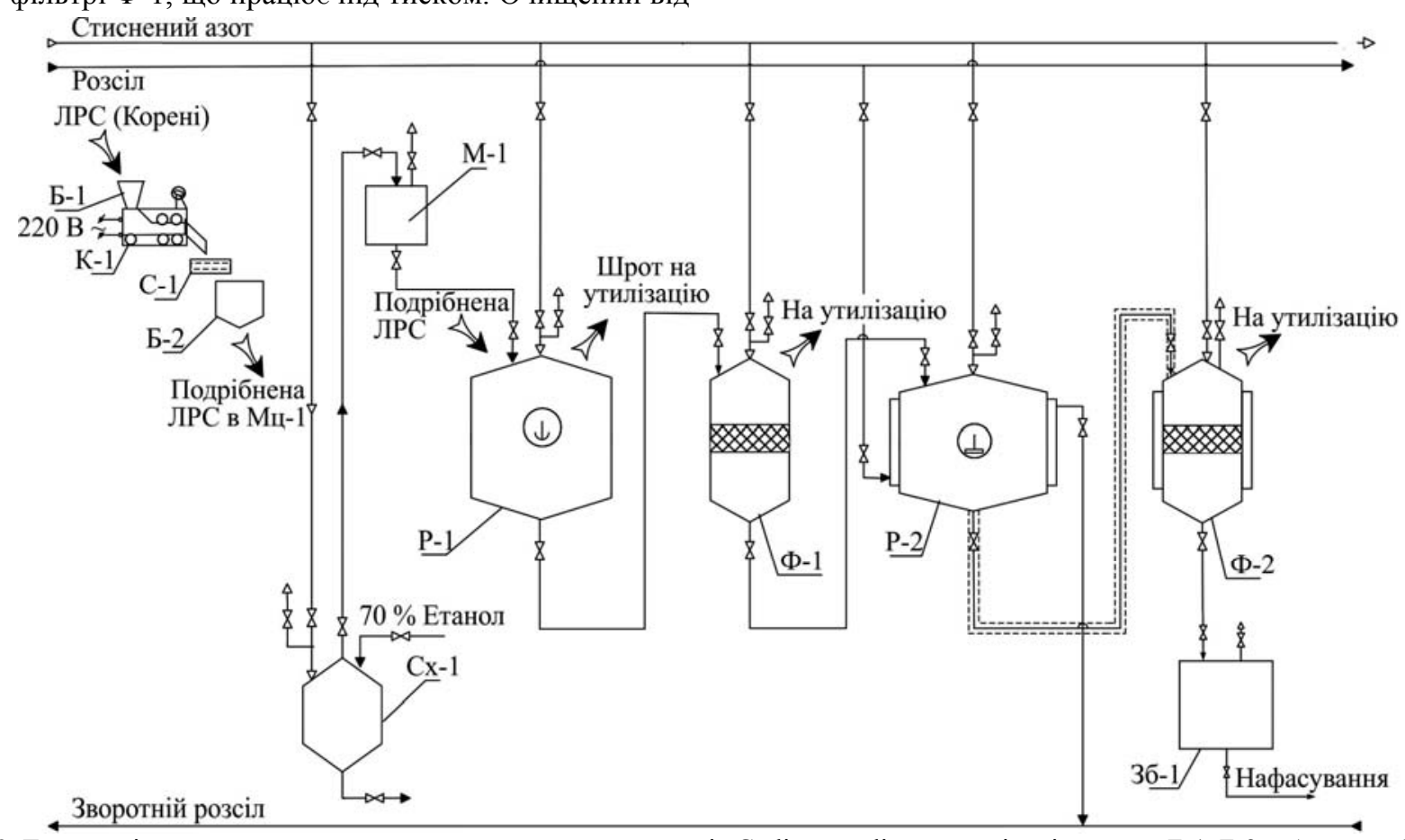

Рис. 2. Технологічна схема процесу одержання настоянок з коренів Carlina acaulis в апараті з мішалкою: Б-1, Б-2 - бункери; Сх-1 сховище; М-1 - мірник; К-1 - коренерізка; С-1 - сито; Р-1, Р-2 - реактори; Ф-1, Ф-2 - друк-фільтри; Зб-1 - збірник

Попередньо підготовлену очищену і висушену рослинну сировину коренів Carlina acaulis подрібнюють у коренерізці К-1, а тоді просіюють на ситах С-1, як це було описано вище. Після цього відсів з розміром час- домішок екстракт збирається в збірник Зб-2, звідки подається на наступну стадію. 3 огляду на отримані експериментальні дані для стандартизації одержаної настоянки було обрано такі показники, як: опис, вміст етанолу, сухий залишок, вміст флавоноїдів, мікробіологічна чистота (табл. 1).

Табл. 1. Показники якості настоянок 3 коренів Carlina acaulis

\begin{tabular}{|c|c|c|}
\hline $\begin{array}{c}\text { № } \\
\text { 3/п }\end{array}$ & $\begin{array}{c}\text { Назва } \\
\text { показника }\end{array}$ & Характеристика та норма \\
\hline 1 & Опис & В'язка маса світло-коричневого кольору \\
\hline 2 & Вміст етанолу & Не більше $15 \%$ \\
\hline 3 & Сухий залишок & Не менше $70 \%$ \\
\hline 4 & $\begin{array}{c}\text { Кількісний вміст } \\
\text { флавоноїдів }\end{array}$ & Не менше 10 г/кг \\
\hline 5 & $\begin{array}{c}\text { Мікробіологічна } \\
\text { чистота }\end{array}$ & $\begin{array}{c}\text { Загальна кількість бактерій не більше } \\
\text { грибів, відсутність бактерій Staphylo- } \\
\text { coccus aureus, Pseudomonas aeruginosa } \\
\text { та групи Enterobacteriaceae }\end{array}$ \\
\hline
\end{tabular}

Після виконаного аналізу, отриману настоянку, що міститься у збірнику 3б-2, подають на інші технологічні стадії (такі, як упарювання), фасують в бочки чи розливають в скляні ємкості. Для дозування і розливу настоянки в скляні флакони використовують роторні або лінійні розливно-дозувальні машини.

Технологічна схема процесу одержання настоянки 3 коренів Carlina acaulis в aпараті 3 мішалкою. У випадку, коли екстрагент перемішується хоч би 3 незначною швидкістю, з'являються конвекційні потоки, які сприяють перенесенню речовини, тобто дифузії. Такий режим екстрагування характерний для мацерації $з$ перемішуванням, яку можна проводити в реакторі 3 мішалкою (рис. 2). тинок 2 мм подають на стадію екстрагування в реактор P-1, який обладнаний якірною мішалкою. Спочатку завантажується подрібнена фітосировина, а тоді через мірник M-1 в реактор зі сховища $\mathrm{Cx}-1$ подається 
екстрагент. Після заповнення апарату, в ньому проводять екстракцію при перемішуванні впродовж 3 годин. Швидкість обертів мішалки становить 60 об/хв.

Отриману настоянку перетискають на фільтрування у друк-фільтр Ф-1. Одержаний на фільтрувальній перегородці осад утилізують, а фільтрат (екстракт) надходить у реактор Р-2, обладнаний сорочкою та лопатевою мішалкою на освітлення.

Освітлення настоянки проводять в реакторі Р-2, за температури $+4-+8{ }^{\circ} \mathrm{C}$, як це було описано вище. Після відстоювання, настоянку холодною фільтрують від частинок, що випали в осад, на друк-фільтрі Ф-2. Очищений від домішок екстракт збирається в збірник 3б-1, звідки подається на наступну стадію стандартизаціі, фасування та упаковування, яку проводять аналогічно до опису в методі настоювання, який розглянули вище. Також досліджено органолептичні та фізико-хімічні показники якості отриманих настоянок, а саме колір, запах, смак, масову частку сухих речовин, $\mathrm{pH}$ та титровану кислотність.

Табл. 2. Органолептичні та фізико-хімічні показники якості отриманих настоянок

\begin{tabular}{|l|c|}
\hline \multicolumn{1}{|c|}{ Показник } & Характеристика/Значення \\
\hline Колір & Світло-коричневий, прозорий \\
\hline Запах & Яскраво-виражений спиртовий \\
\hline Смак & 3 гірчинкою \\
\hline $\begin{array}{l}\text { Масова частка сухих речо- } \\
\text { вин, \%, не менше }\end{array}$ & 14,2 \\
\hline рН & 6,45 \\
\hline Титрована кислотність, град. & 0,3 \\
\hline
\end{tabular}

3 табл. 2 можна зробити висновок, що отримані настоянки мають високі органолептичні характеристики, високий вміст сухих речовин, що вказує на ефективну екстракцію, низький рН та кислотність.

Одержання екстракту коренів Carlina acaulis. Коpeні Carlina acaulis подрібнено та просіяно крізь сито 3 розміром отворів 3,0 мм. 3 літератури відомо, що найоптимальнішим ступенем подрібнення сировини є 2,0 3,0 мм, оскільки частинки 3 меншим ступенем подрібнення можуть закупорювати фільтри на етапі фільтрації екстрактів на виробництві. Для наступних дослідів брали по 10,0 г/5,0 г наважки і додавали $70 \%$ та $40 \%$-й розчини етанолу, настоювали 7 діб. Також такі самі розчини паралельно екстрагували в колбах на магнітній мішалці впродовж 1 год за нагрівання до $40{ }^{\circ} \mathrm{C}$ із зворотнім холодильником та в апараті Сокслета. Отримані екстракти профільтровано, стандартизовано та визначено вміст фенольних сполук та флавоноїдів (табл. 3). Як екстрагент використано 70 \%-й розчин етанолу. Екстракцію проведено методом настоювання та в апараті з мішалкою, використовуючи співвідношення 1:10.

Вміст фенольних сполук у досліджуваних екстрактах визначали спектрофотометрично з використанням реагенту Фоліна-Чекольтеу та виражали у відсотках (див. табл. 3). До 2 мл екстракту додавали 1 мл реагенту Фоліна-Чекольтеу, 10 мл води, перемішували, доводили до 25 мл розчином натрію карбонату і перемішували. Паралельно готували розчин із стандартним зразком галової кислоти. Розчини витримували 30 хв і вимірювали оптичну густину на спектрофотометрі за довжини хвилі 760 нм у кюветі з товщиною шару 10,0 мм. Загальний фенольний вміст у досліджуваних екстрактах становив від 0,203 до 1,326\%. Отримані результати вмісту флавоноїдів у досліджуваних екстрактах, визна- чених за допомогою спектрофотометричного методу, подано у табл. 3.

Вміст суми флавоноїдів у досліджуваних екстрактах визначали спектрофотометрично 3 хлоридом алюмінію в перерахунку на рутин за довжини хвилі 430 нм. До 1 мл екстракту додавали 5,0 мл 70 \%-го етанолу, 5,0 мл $5 \%$-го розчину алюміній хлориду в етанолі, 2,0 мл 5 \%ї оцтової кислоти в етанолі, доводили до 25 мл етанолом і перемішували. Паралельно готували розчин із стандартним зразком рутину. Розчини витримували 30 хв і вимірювали оптичну густину на спектрофотометрі за довжини хвилі 760 нм у кюветі з товщиною шару 10,0 мм. Загальний вміст флавоноїдів у досліджуваних екстрактах становив від 0,180 до 0,852 \%.

Табл. 3. Загальний вміст фенолів і флавоноїдів в екстрактах рослинної сировини коренів С. acaulis, $+\Delta x(n=3)$

\begin{tabular}{|c|c|c|c|c|}
\hline Спосіб & Екстра & $\begin{array}{c}\text { Співвідно- } \\
\text { екення сиро- }\end{array}$ & \multicolumn{2}{|c|}{$\begin{array}{c}\text { Вміст вторинних } \\
\text { метаболітів, \% }\end{array}$} \\
\cline { 4 - 5 } & гент & $\begin{array}{c}\text { вина: екстра- } \\
\text { гент }\end{array}$ & $\begin{array}{c}\text { сума феноль- } \\
\text { сума сполук }\end{array}$ & $\begin{array}{c}\text { сула- } \\
\text { воноїдів }\end{array}$ \\
\hline Настоювання & $\begin{array}{c}70 \% \\
\text { етанол }\end{array}$ & $1: 10$ & $1,325^{ \pm 0,045}$ & $0,852^{ \pm 0,010}$ \\
\hline $\begin{array}{c}\text { Перемішуван- } \\
\text { ня в апараті з } \\
\text { мішалкою }\end{array}$ & $\begin{array}{c}70 \% \\
\text { етанол }\end{array}$ & $1: 10$ & $0,954^{ \pm 0,092}$ & $0,329^{ \pm 0,006}$ \\
\hline
\end{tabular}

Отримані результати дослідження є розроблені вперше, тому неможливо порівняти 3 відомими технологічними схемами для одержання екстрактів C. acaulis.

\section{Висновки}

Внаслідок проведеного дослідження розроблено дві технологічні схеми екстракції коренів C. acaulis, які враховують максимальні виходи фенольних сполук і флавоноїдів, тривалість екстракції, подрібнення сировини. У першій технологічній схемі розроблено одержання екстрактів коренів $C$. acaulis методом настоювання. Одержану настоянку стандартизовано та отримано високі показники сухого залишку, вмісту флавоноїдів та мікробіологічної чистоти. У другій технологічній схемі розроблено одержання екстрактів коренів C. acaulis методом настоювання 3 перемішуванням, отримані настоянки мають високі органолептичні характеристики та високий вміст фенольних сполук і флавоноїдів.

За результатами дослідження 3 визначення фенольних сполук і флавоноїдів зробили висновки, що розроблені технологічні схеми дають змогу отримувати максимальну кількість вторинних метаболітів 3 використанням 70 \%-ї водно-етанольної суміші, співвідношення сировина: екстрагент - 1:10 та тривалістю екстракції 48 год при настоюванні та 3 год при настоюванні 3 перемішуванням. Одержані настоянки можна застосовувати як лікарський засіб або як компонент у комплексних засобах.

\section{References}

1. Cardoso, J. C., Oliveira, M. E. Bs., \& Cardoso, F. Ci. (2019). Advances and challenges on the in vitro production of secondary metabolites from medicinal plants. Horticultura Brasileira, 37, 124 132. https://doi.org/10.1590/S0102-053620190201

2. Dordevica, S., Tadica, V., Petrovic, S., Kucic-Markovic, Je., Dobric, S., Milenkovic, M., \& Hadzifejzovice, N. (2012). Bioactivity assays on Carlina acaulis and C. acanthifolia root and herb extracts. Digest Journal of Nanomaterials and Biostructuresm 7(3), 1213-1222. 
3. Hrodzinskyi, A. M. (1992). Likarski roslyny: entsyklopedychnyi dovidnyk. Kyiv: Vydavnytstvo "Ukrainska Entsyklopediia" im. M. P. Bazhana. Ukrainskyi vyrobnycho-komertsiinyi tsentr "Olimp", 544 p. [In Ukrainian].

4. Knyha. (2020). Chervona knyha Ukrainy. Retrieved from: https://redbook-ua.org/. [In Ukrainian].

5. Kyiak, V. (2003). Populiatsiine riznomaittia roslyn vysokohiria Karpat. Proceedings of the Taras Shevchenko Scientific Society. Ecological problems of the Carpathian region, 12, 192-202. [In Ukrainian].

6. Meusel, H., \& Kästner, A. (1990). Lebensgeschichte der Goldund Silberdisteln. Monographie der mediterran-mitteleuropäischen Compositen-Gattung Carlina: Band I. Springer-Verlag, Wien, New York, $236 \mathrm{p}$.

7. MSOP. (2020). Chervonyi spysok MSOP (IUCN Red List of Threatened Species). Retrieved from: https://www.iucnredlist.org. [In Ukrainian].

8. Raina, R., Chand, R., \& Sharma, Y. P. (2011). Conservation strategies of some important medicinal plants. Int. J. Med. Aromat. Plant, 1(3), 342-347

9. Ruban, O. A., Malynovska, S. A., Al-Tovaiti, Murad, \& Mazurets, S. I. (2012). Perspektyvy stvorennia novykh oryhinalnykh preparativ na pidstavi substantsii roslynnoho pokhodzhennia. $\mathrm{Fi}$ toterapiia. Chasopys, 2, 63-65. [In Ukrainian].

10. Strzemskia, M., Wójciak-Kosiora, M., Sowaa, I., Załuskib, D., Verpoortec, R. (2019). Historical and traditional medical applications of Carlina acaulis L. A critical ethnopharmacological review. Journal of Ethnopharmacology, 239, 123-132. https://doi.org/10.1016/j.jep.2019.111842

11. Stuttgart. (2002). Wichtl-Teedrogen und Phytopharmaka, Stuttgart, Wissenschaftliche Verlagsgesellschaft, mbH Stuttgart, $240 \mathrm{p}$.

12. Trejgell, A., Bednarek, M., \& Tretyn, A. (2009). Micropropagation of Carlina acaulis L. Acta biologica cracoviensia. Series: Botanica, 51(1), 97-103.

13. Trejgell, A., Dabrowska, G.-B., \& Tretyn, A. (2009). In vitro regeneration of Carlina acaulis subsp. simplex from seedling explants. Acta Physiologiae Plantarum, 31(3), 445-453. https://doi.org/10.1007/s11738-008-0252-5

14. Vyshnevska, L. I. (2008). Tekhnolohichni doslidzhennia likarskoi roslynnoi syrovyny ta yii kompozytsii u stvorenni novykh preparativ. Visnyk farmatsii, 4, 33-38. [In Ukrainian].

15. Yefremova, O. O., Skybitska, M. I., Meleshko, I. H., et al. (2009). Biolohichni osoblyvosti rostu i rozvytku vydiv rodu Carlina L. EXSITU. Forestry and agroforestry, 115, 245-249. [In Ukrainian].

O. M. Fedoryshyn, D. S. Zahorodnia, A. S. Krvavych, A. O. Mylyanych, R. O. Petrina Lviv Polytechnic National University, Lviv, Ukraine

\section{DEVELOPMENT OF TECHNOLOGICAL SCHEME OF CARLINA ACAULIS ROOT'S EXTRACTION}

The urgent task in obtaining pharmaceuticals is to receive secondary metabolites of medicinal plants. Carlina acaulis is a medicinal plant that is currently understudied. In folk and traditional medicine there is information on the use of extracts of the root in some complex drugs. In folk and traditional medicine, there is information on the use of extracts of the root in some complex drugs. The Carlina acaulis roots contain tannins and resinous substances, inulin (12-18\%), dyes, essential oil (1-2 \%), and sugar. It is necessary to choose the right effective extraction technology for maximum extraction of phenolic compounds and flavonoids. Technological schemes have been developed on the basis of kinetic regularities of extraction in two ways - infusion and infusion with stirring in the device with a stirrer. As an extractant $70 \%$ aqueous-ethanol mixture is proposed, the ratio of raw materials is extractant 1:10, particle size is $2 \mathrm{~mm}$. It is established that the extraction time by the infusion method is 48 hours. The extraction time by the infusion method with stirring is 3 hours. The resulting tincture has viscous consistency, light brown colour with an ethanol content of not more than $15 \%$, and a dry residue of not less than $70 \%$. The obtained tincture was tested for microbiological purity. The technological scheme of production includes preparation of plant material (grinding, sifting, weighing), obtaining the primary extract (maceration), filtration and lighting tincture (purification from ballast substances by cooling, settling, filtration, etc.). The authors have drawn the conclusion that the obtained extracts of Carlina acaulis roots will contain the maximum yield of phenolic compounds and flavonoids on the basis of the developed technological schemes. The obtained tinctures have high organoleptic and physicochemical parameters and can be used as a medicine.

Keywords: extract; infusion; phenolic compounds; flavonoids; secondary metabolites; technological scheme. 